\title{
CIÊNCIANATURA
}

\section{Synoptic patterns for days with intense atmospheric electrical activity from 2013 to 2015}

\author{
Vanessa Gehm Rodrigues, Everson Dal Piva, Franciano Scremin Puhales and Vagner Anabor
}

Universidade Federal de Santa Maria - UFSM, Santa Maria, RS, Brasil

\section{Abstract}

The following study aimed to analyze data from Atmospheric Electric Discharge (AEDs) from the period between 2013 to 2015, with the objective of obtaining atmospheric patterns for the days with the maximum AED detected near the city of Santa Maria, in the state of Rio Grande do Sul. Data from the Sferics Timing and Ranging NETwork (STARNET) have been used. With a FORTRAN routine, a search at the AED data was performed to obtain the daily maximum of AED in an area of $1^{\circ}$ per $1^{\circ}$ centered in the city Santa Maria. One day of each year were found with maximum numbers of AEDs. The gridded atmospheric dataset used to dynamic and thermodynamic analysis were the final analysis from the National Centers for Environmental Prediction (NCEP). The main characteristics found were the proximity of the equatorial entrance of the high-level jet streak and the thermodynamics indices indicating moderate-to-high possibility for storm occurrence. This analysis enabled in the atmospheric characterization associated to events with large daily amount of DEAs and can be used to improve forecast.

Keywords: Lightning, thunderstorm, atmospheric patterns. 


\section{Introduction}

Atmospheric Electric Discharges (AEDs) associated with convective storms have great importance because of their destructive power, causing deaths and economic losses to society. After floods, AED is the main cause of death by natural phenomena in the world (Pinto Jr; de Almeida Pinto, 2008). According to the Atmospheric Electricity Group (ELAT, 2000-2014), it is estimated that 50 million AEDs occur every year around the world and one in fifty deaths caused by AEDs occurs in Brazil. In the economic sector, AEDs affects industries and households due to equipment flaring and disconnection of transmission and distribution lines, as well as the burning of transformers (Pinto Jr; de Almeida Pinto, 2000). AEDs occur due to the accumulation of electrical charges from collisions of ice crystal particles and hail in regions within thunderstorm clouds, referred to as cumulonimbus clouds, and may rarely occur in stratocumulus or nimbostratus clouds (Politi et al., 2006). These discharges begin due to the production of the electric field, which thus exceeds the dielectric strength or the insulating capacity of the air in a certain place of the atmosphere (Mattos, 2009).

Lightning strikes are defined as several individual AEDs with large dimensions (a few kilometers) and great intensity occurring in the troposphere. They are classified as: intercloud, intracloud, from the cloud to some point in the atmosphere (discharges into the air), cloud-to-ground and ground-to-cloud. The latter two ones are the most important due to their destructive power over society (Pinto Jr; de Almeida Pinto, 2008).

Lightning is just one of the AED's electrical impulses from the cloud to the earth. Lightning strikes the air around it violently, causing the air to reach maximum temperatures of up to 30,000 $\mathrm{C}$ in about 10 microseconds. This heated air expands to generate an intense sound wave known as thunder and spreads in all directions. Thunder produced by cloud-to-ground lightning typically has a maximum intensity of around 50-100 Hz and can be heard up to distances of $20 \mathrm{~km}$, whereas lightning produced between clouds are weaker with a maximum intensity around of 20-30 Hz (Pinto Jr; de Almeida Pinto, 2000).

Convection in the subtropics of South America presents patterns consistent with the life cycles of storms starting in the Andes and growing in larger Mesoscale Convective Systems (MCSs) that propagate to the east towards southern Brazil. In the Prata basin, MCSs are very important in generating deep convection, with high precipitation rates associated to extreme events (Rasmussen et al., 2016). In this way, the maximum amount of cloud-to-ground AED occur when the system is close to maturation, reaching the largest convective area (Mattos; Machado, 2011). The following research aimed to obtain atmospheric patterns for the days with the largest number of AED detected near the city of Santa Maria, in the central region in the state of Rio Grande do Sul, southern Brazil.

\section{Methodology}

For this study we used data from the STARNET (2011) (Sferics Timing And Ranging NETwork) which is a system composed of a set of receiving antennas that operate on a frequency VLF (Very Low Frequency - 7 e $15 \mathrm{kHz}$ ) and detect radio noise emitted by AED. These noises are called sferics and can propagate thousands of miles imprisoned in the waveguide delimited by the earth's surface and the ionosphere. This system operates by locating the AED in its coverage area through a concept developed by Lee (1986) called ATD (Arrival Time Difference)(Lee, 1986b). The network has been operating since 2006, but only in 2013 a reception antenna was installed in Trellew-Argentina (Figure1). This antenna locates southern Brazil within the network (i.e., not at the edge of the network), making the data more reliable in this region. So, we chose to work only with data from 2013, 2014 and 2015. STARNET data were acquired through the ZEUS website (http://www.zeus.iag.usp.br), which is maintained by the University of São Paulo.

A FORTRAN routine was developed to perform a search on the AED data and determine the day of each year in which the maximum AED occurred in an area of $1^{\circ} \times 1^{\circ}$ centered in the city of Santa Maria, in the state of Rio Grande do Sul. After obtaining the day of more lightning of each year, meteorological fields were generated using the graphic package GrADS. The atmospheric data used comes from the NCEP (1999) (National Centers for Environmental Prediction) and is known as Final Analysis (http://rda.ucar.edu/datasets/ds083.2). These data have horizontal grid spacing of 1 x 1 lat x lon and 26 pressure levels, available at six-hour intervals. These data can be obtained through the (GFS) (Global Forecast System), but are prepared about an hour after the start of the GFS operational numerical prediction because they assimilate an additional dataset (NCEP, 2000). The variables used were the thickness in the 1000-500 hPa layer, Sea Level Pressure (SLP), horizontal wind vectors, convective available potential energy (CAPE in the lowest $180 \mathrm{mb}$ layer) and precipitable water.

Thermodynamic profiles were also available from the University of Wyoming Department of Atmospheric Science (http://weather.uwyo.edu/upperair/sounding.html). Satellite images in the enhanced infrared channel, obtained in the database of the Center for Weather Forecasting and Climate Studies (CPTEC) / National Institute of Space Research (INPE) (http://satelite.cptec.inpe.br/home/index.jsp). 
Figure 1- Location of the AED receiving antennas in South America

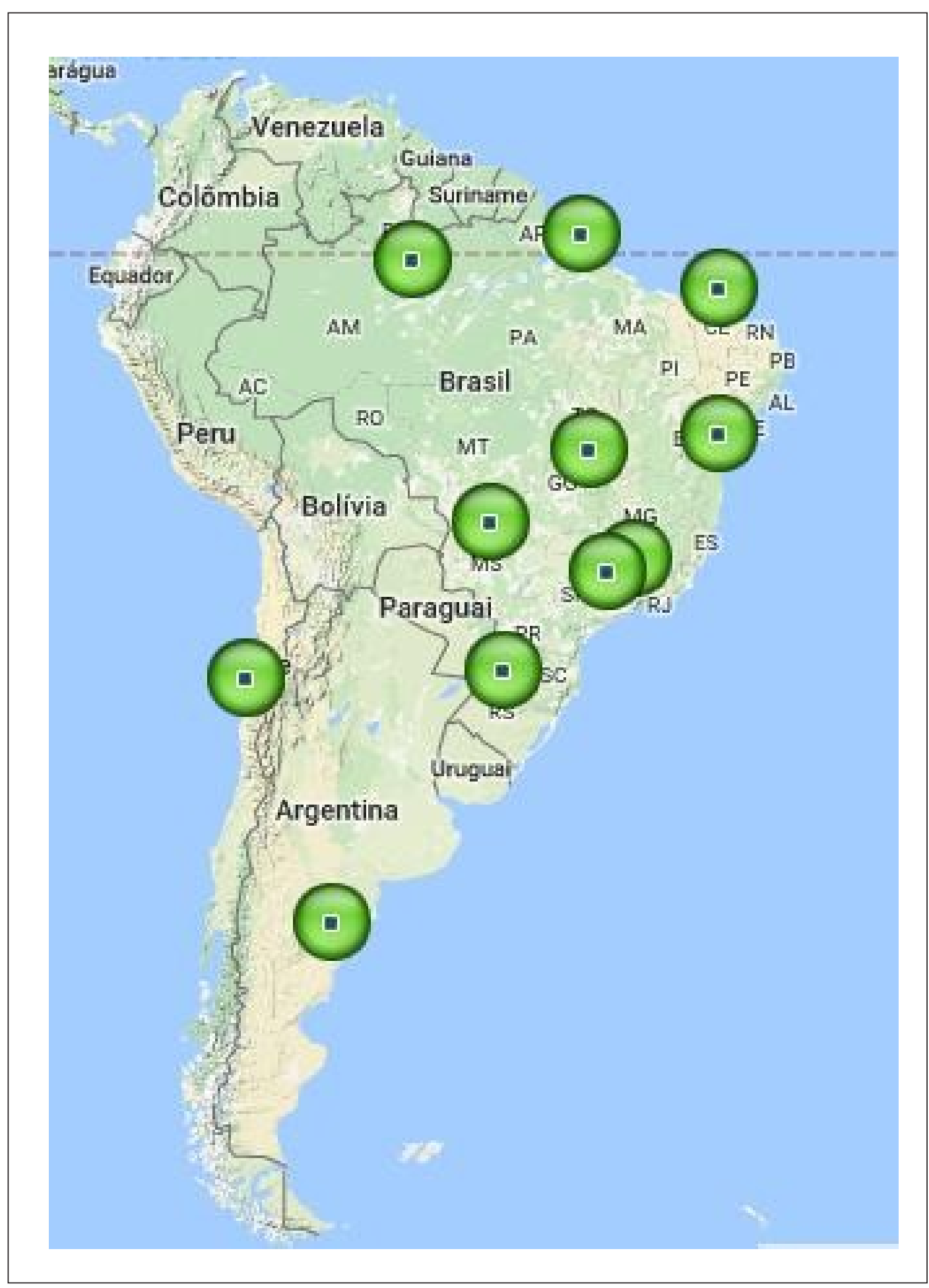




\section{Results and discussions}

The largest amount of daily AED near the city of Santa Maria-Rio Grande do Sul were recorded at: November 11, 2013 with 3601 lightning, October 17, 2014 with 5250 lightning and July 13, 2015 with 6904 lightning (Figure 2). Analyzing Figure 2 , it can be seen that in all three cases a large amount of daily AED occurred in the RS, but in the western / central region of the state, the DEA peaks were much more significant.

Figure 2 - Spatial distribution of daily AED on days November 11, 2013 (a); October 17, 2014 (b) and July 13, 2015 (c). The black circle indicates the town of Santa Maria-Rio Grande do Sul
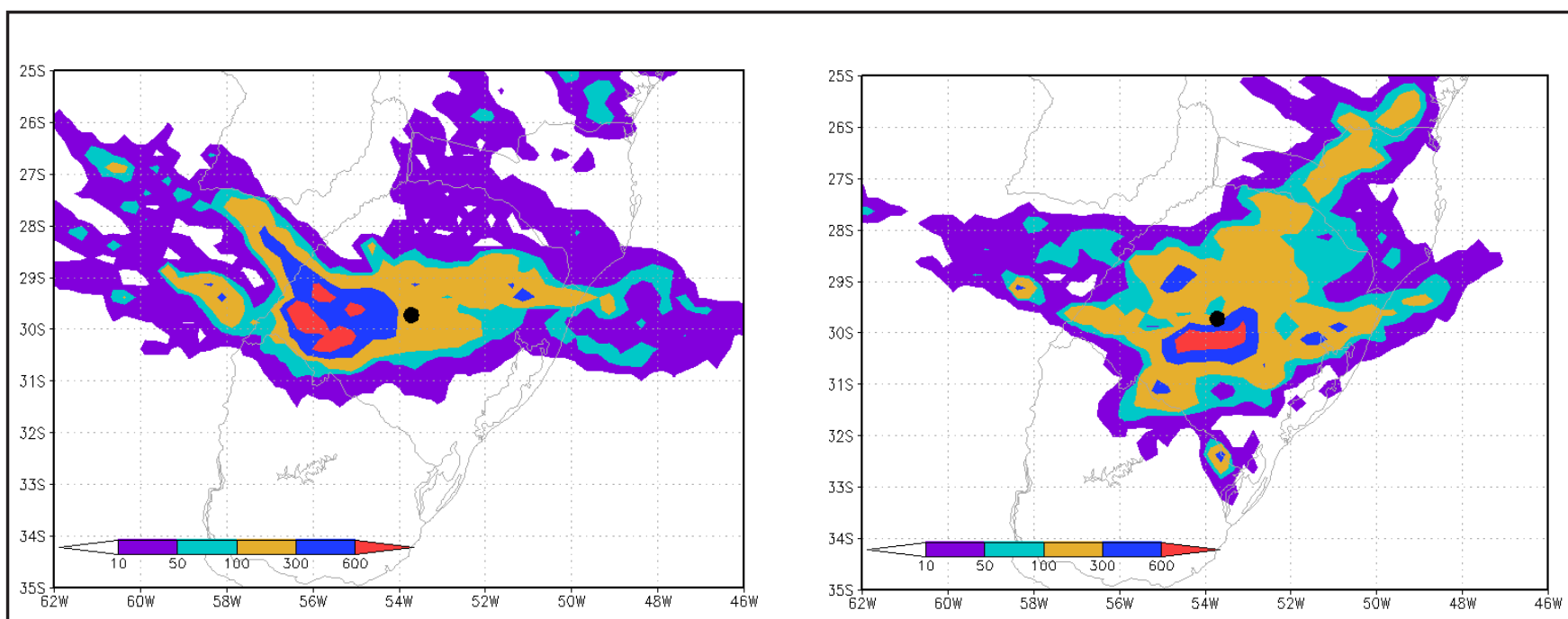

(a)

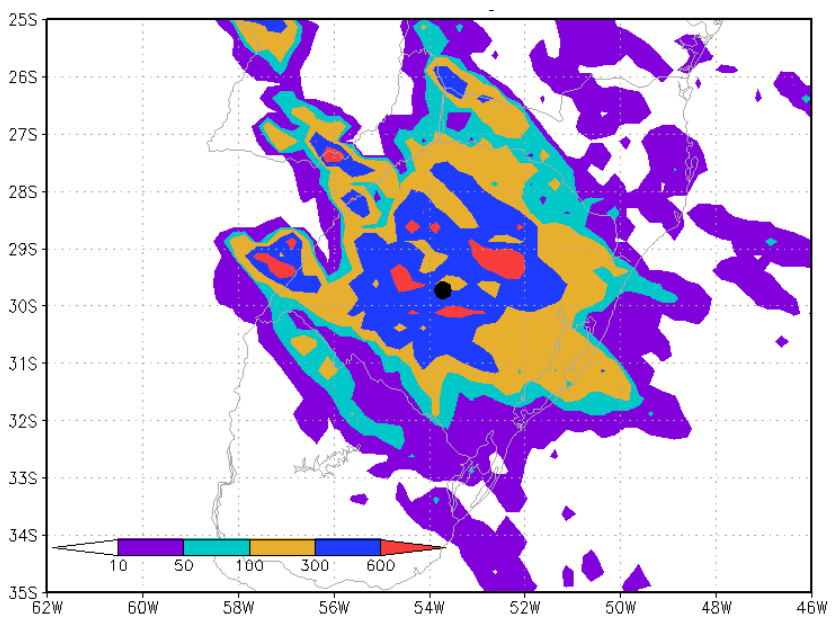

(c) 


\subsection{November 11, 2013 - 3601 AED near Santa Maria-Rio Grande do Sul}

In the first hours of the day the convective nuclei are intense on almost all on the state of Rio Grande Sul, and they move eastward, dissipating into the night. Although the cluster of clouds moves to the northeast, new cells tend to form northwestward of the oldest (Figure 3). The region where a large convective activity with cooler cloud tops occurs, partially corresponds to the great amount of daily AED (Figure 2a).

Analyzing Figure 4, it is observed the presence of an extratropical cyclone over the South Atlantic in the SLP field and a trough that extends northwest to Paraguay, passing through Santa Maria (Figure 4a). The 1000-500 hPa layer thickness shows the presence of a thickness gradient between Argentina and Brazil/Paraguay indicating a baroclinic region, that is, a horizontal temperature gradient pointing to the northeast with the existence of cold and warm air across this gradient (Figure 4a). In the upper-level wind field (Figure 4b), there is a shortwave trough over Argentina and the equatorial entrance of the subtropical jet streak is located over the state of Rio Grande do Sul. The entrance of the jet streak induces a transverse circulation which generates upward movement over the state. The CAPE field shows values above $1000 \mathrm{~J} / \mathrm{kg}$ in Paraguay and Paraná (Figure 4c), while the flow at $850 \mathrm{hPa}$ indicates northwesterly flow that extends from the Amazon basin to the state (Figure 4c). This flow coincides with the high thickness observed in Figure $4 \mathrm{a}$ and with high precipitable water (above $50 \mathrm{~mm}$ ) in the state of Rio Grande do Sul (Figure 4c). Based on the thermodynamic profile (Figure 4d), the indices favorable to convective activity are K, Total Totals (values above 30) and Sweat (value of 240). The Showalter index was not favorable to convection since it indicated a value of 0.13 . It is also noted that the height of the freezing level is low, at $600 \mathrm{hPa}$, which helps in the freezing of raindrops and consequently in the possibility of electrification of the cloud due to the presence of ice.

Figure 3 - Enhanced infrared satellite image at: 0300 UTC (a), 0900 UTC (b), 1500 UTC (c) e 2100 UTC (d) November 11,2013

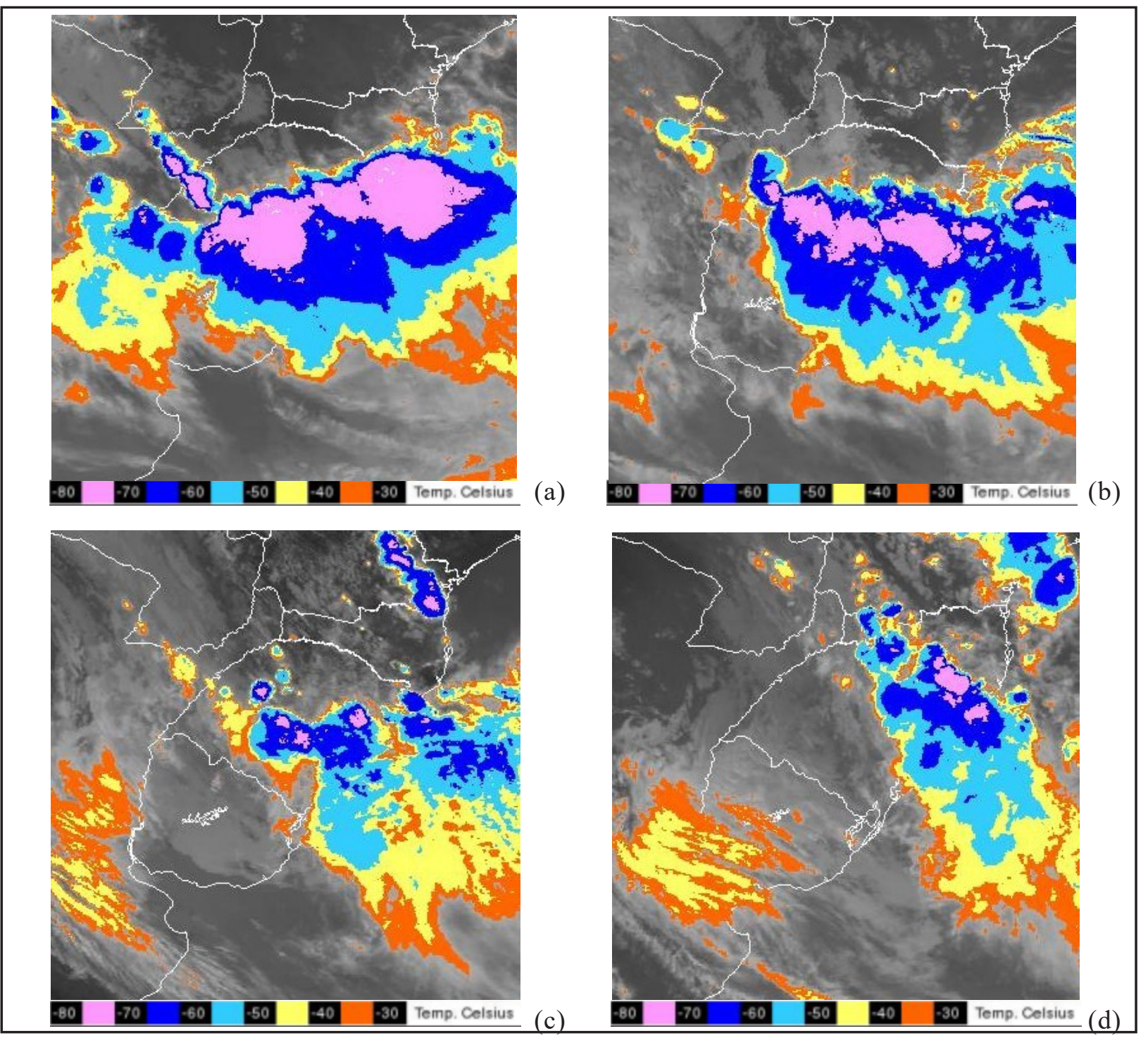


Figure 4 - Meteorological fields for November 11, 2013 at 12 UTC: (a) SLP (black line, 2 hPa) and 1000-500 hPa thickness (colored, $60 \mathrm{~m}$ ); (b) current lines (black) and wind magnitude (colored, every $10 \mathrm{~m} / \mathrm{s} \mathrm{from} 30 \mathrm{~m} / \mathrm{s}$ ) at $200 \mathrm{hPa}$; and (c) current lines at $850 \mathrm{hPa}$ (black), precipitable water (blue dashed, $10 \mathrm{~mm}$ ) and CAPE (colored, above $400 \mathrm{~J} / \mathrm{kg}$ ). (d) Thermodynamic profile in Santa Maria for the same time of the meteorological fields

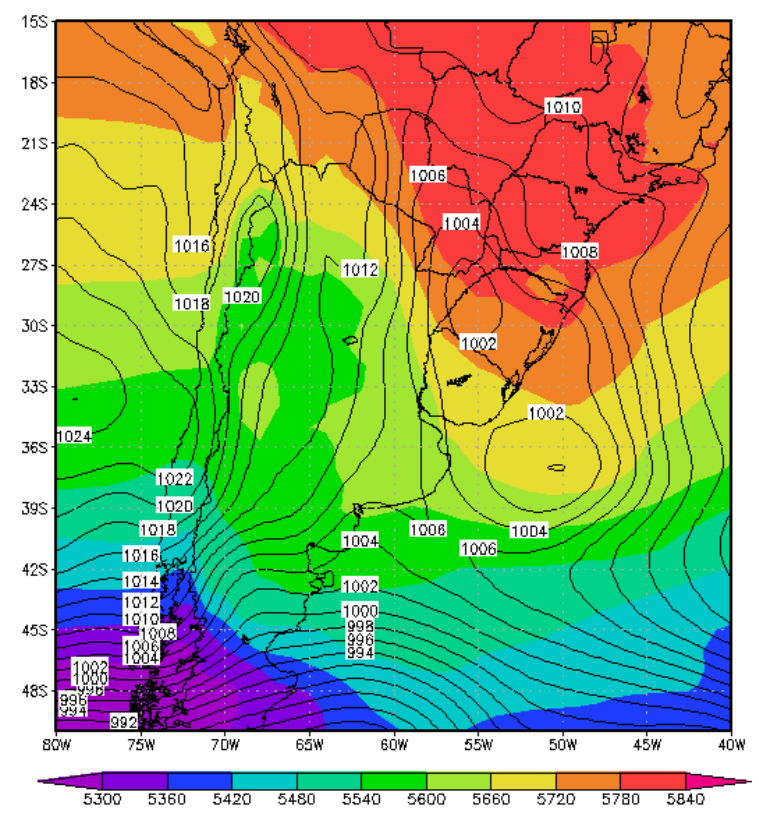

(a)

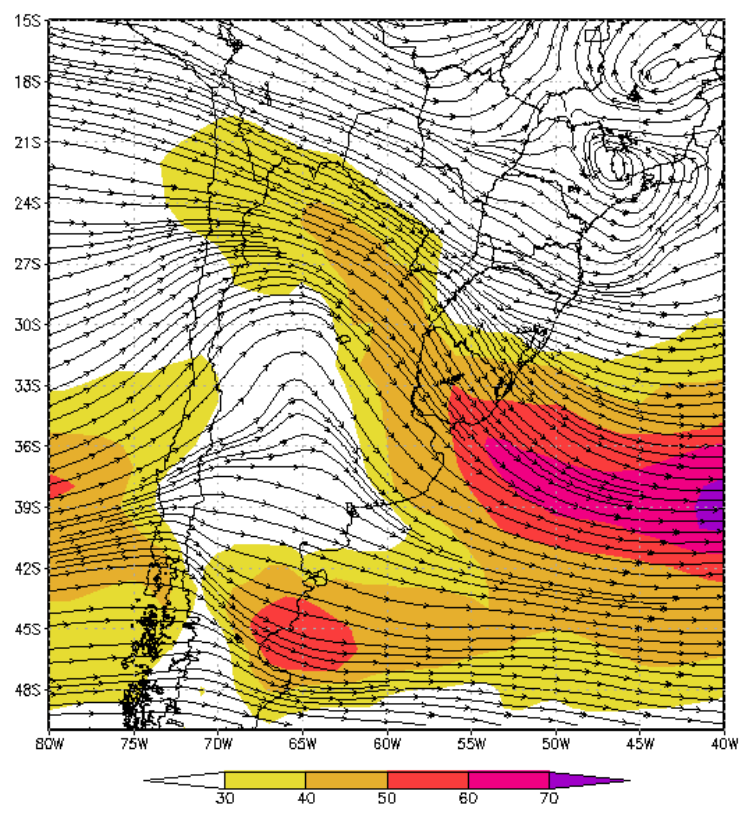

(b)

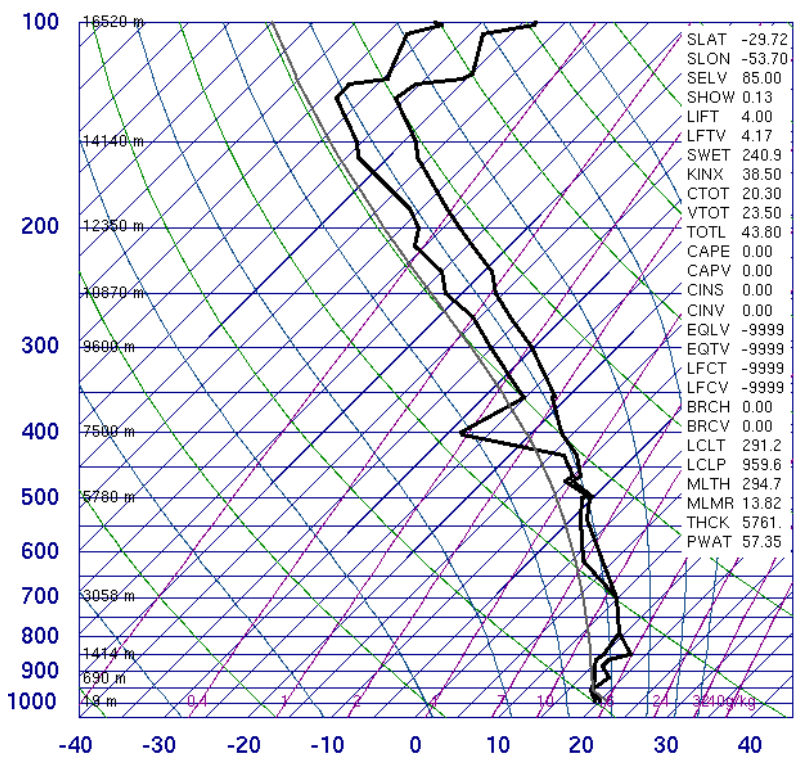

(c) 


\subsection{October 17, 2014 - 5250 AED near Santa Maria-Rio Grande do Sul}

Figure 5 shows that the convective nuclei are intense in the morning period on almost all over the state of Rio Grande do Sul, disappearing during the day. Unlike the previous case, the cluster of clouds moves to the northeast but new cells tend to form westward from the oldest. In this case, the highest amount of daily AED (Figure $2 b$ ) coincides with the maximum convective activity.

Analyzing the fields in Figure 6, a low-pressure system is observed over northern Argentina and a baroclinic region which is located over the south of Brazil is more intense than in the previous case (Figure 4a), but the warmer air is now over Paraguay. This establishes a thermal gradient that points to northwest over the state of Rio Grande do Sul (Figure 6a). At $200 \mathrm{hPa}$, the flow is almost zonal and the equatorial entrance of the subtropical jet streak is located near (downstream) the polar exit region of the jet streak. Therefore, there are two transverse circulations that are forcing upward motion in the area between southern Brazil and central Argentina (Figure 6b), one associated with the equatorial entrance and other with the polar exit. At $850 \mathrm{hPa}$, the flow is from the Amazon basin, but with strong cyclonic circulation over northern Argentina (Figure 6c). The CAPE is large near the thickness gradient region, but on the state of Rio Grande do Sul it is below $800 \mathrm{~J} / \mathrm{Kg}$ (Figure $6 \mathrm{c}$ ). Precipitable water is high $(50 \mathrm{~mm})$ as in the previous case (Figure $6 \mathrm{c}$ ). Considering the thermodynamic profile, the Showalter instability index is not very favorable to convection (value of 2.03; Figure $6 \mathrm{~d}$ ). When considering the favorable indices, the $\mathrm{K}$ index showed a value of 35 , indicating the possibility of occurrence of isolated storms, and Total Totals with a value of 42 , suggesting a possibility of moderate storms (Figure 6d). As in the previous case, the height of the freezing level is also low (at $600 \mathrm{hPa}$ ), making possible the cloud electrification.

Figure 5 -The same as in Figure 3, but October 17, 2014

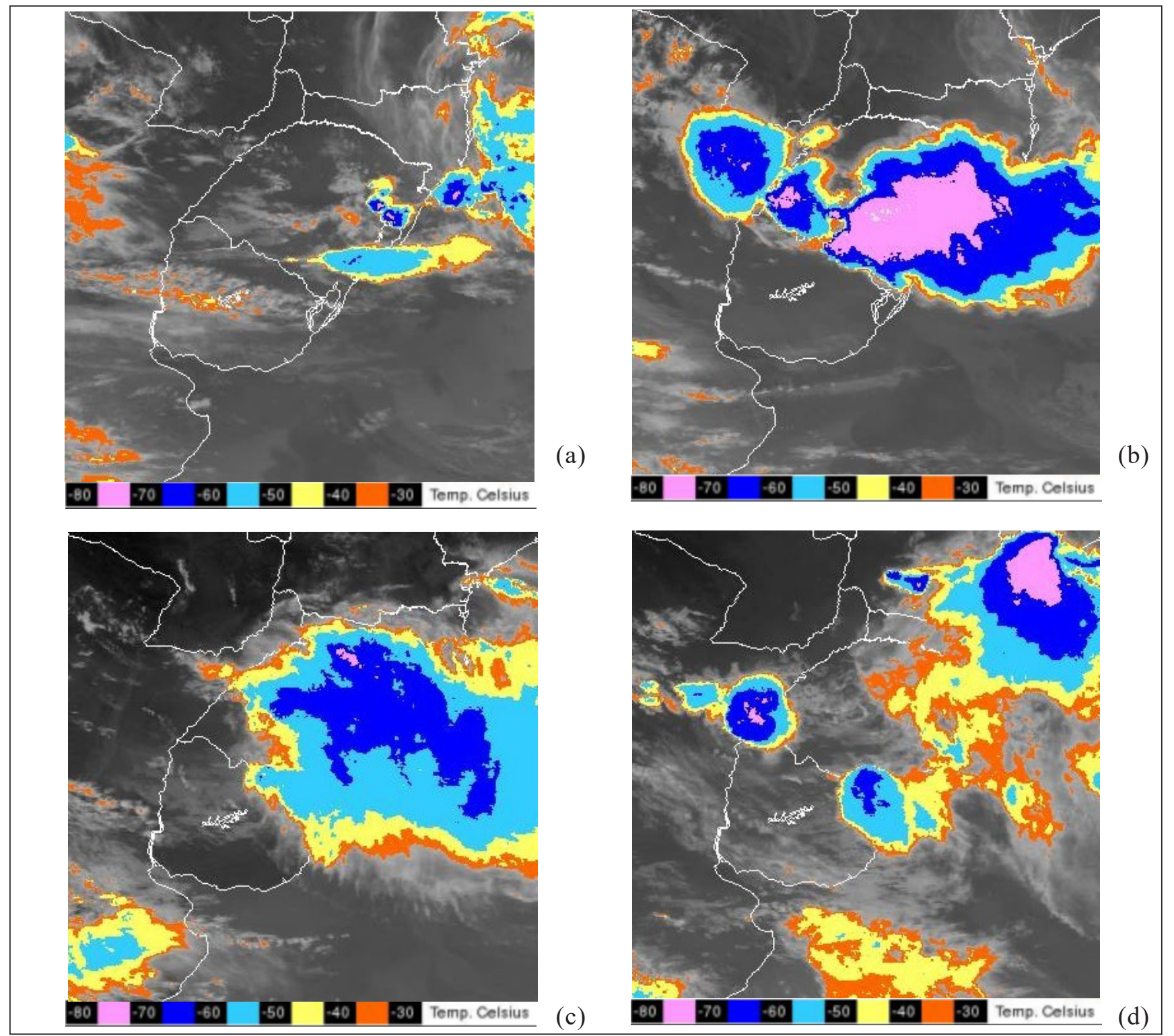




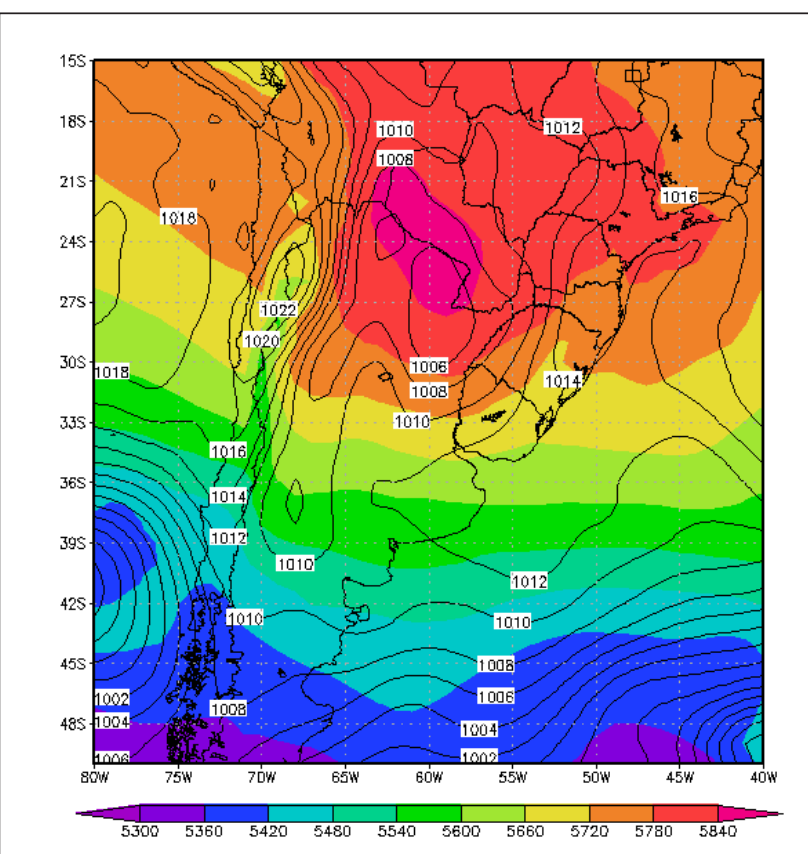

(a)

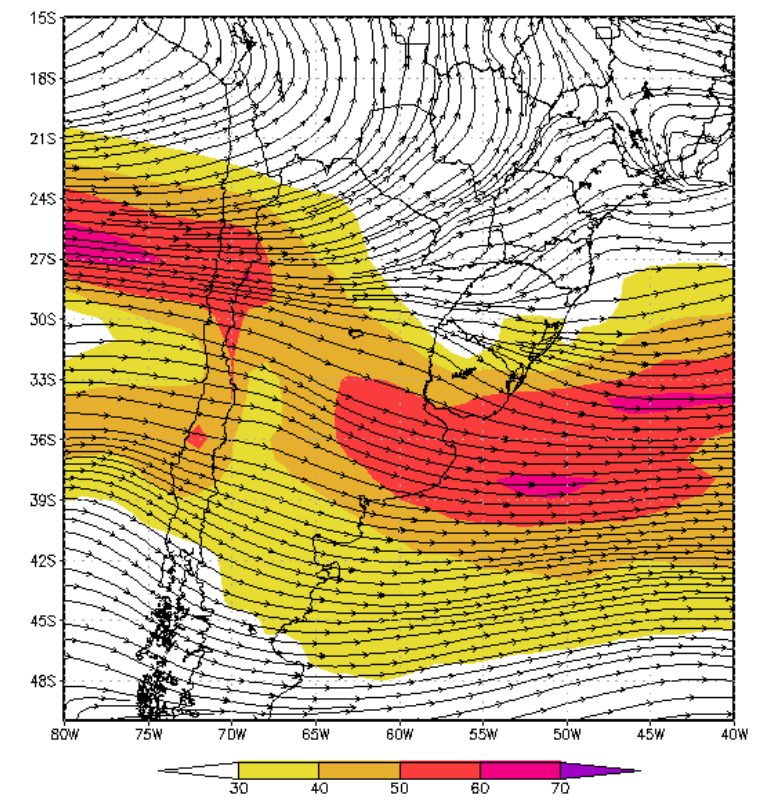

(b)
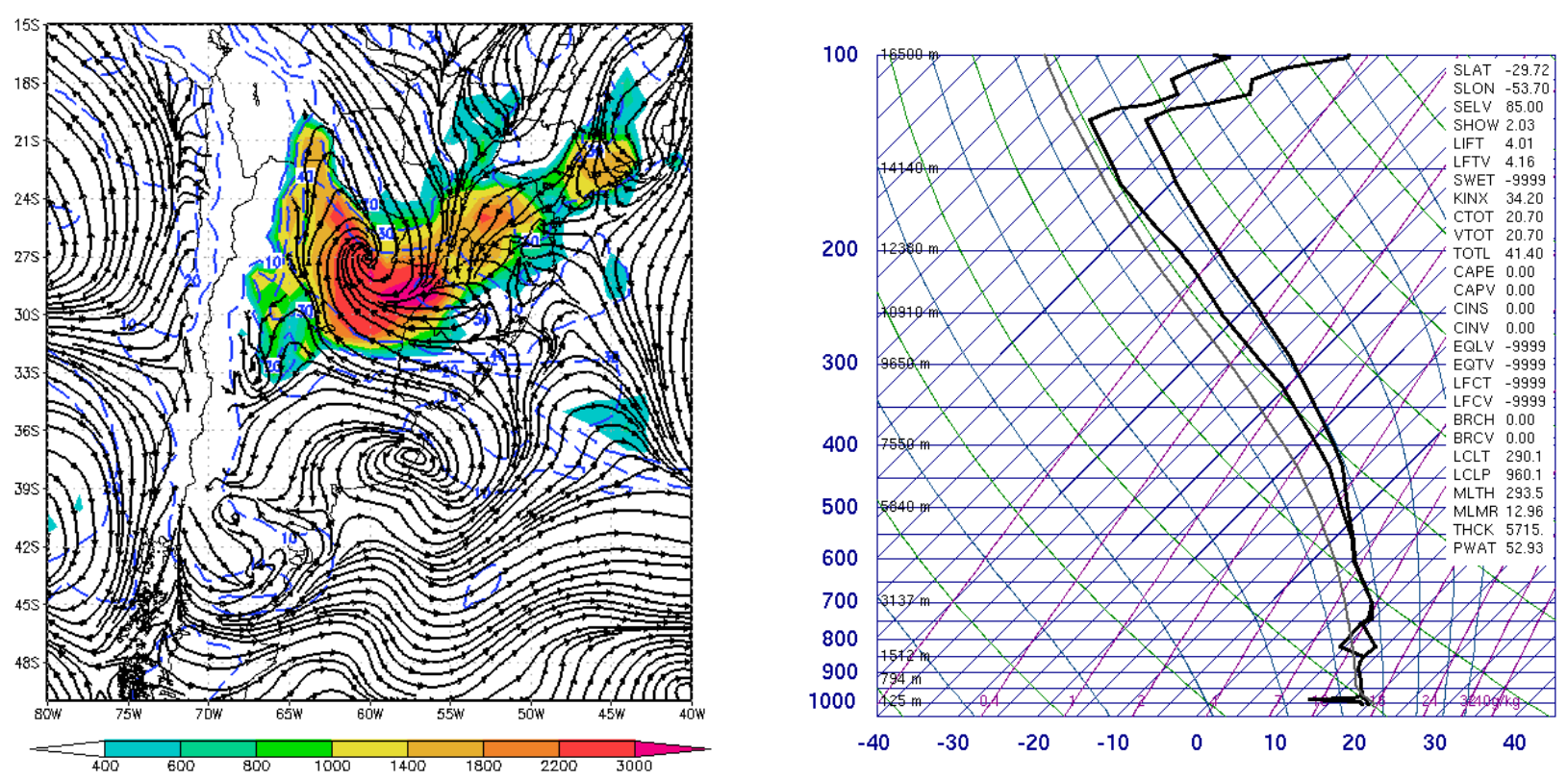

(c) 


\subsection{July 13, 2015 - 6904 AED near Santa Maria-Rio Grande do Sul}

Differently from previous cases, the intense convective activity occurs throughout the day over the whole of the Rio Grande do Sul state area (Figure 7). In this way, this case is what concentrates the highest activity of daily AED, (figura 2c) covering the entire state and coinciding with the maximum convective activity.

A quite different configuration (Figure 8) is observed with respect to the previous cases (Figure 4 and 6). The state of Rio Grande do Sul is located in a col region, with a strong baroclinic zone in the north of Argentina and a weak baroclinic region over the state of Rio Grande do Sul (Figure 8a). At $200 \mathrm{hPa}$, a large-scale trough is observed and the equatorial entrance of the subtropical jet streak is near the polar exit region of a downstream polar jet streak. Thus, as second case, there are two transverse circulations which force upward motion in the area between Southern Brazil and northern Argentina/Paraguay (Figure 8b). At $850 \mathrm{hPa}$, there is strong confluence in northern of Argentina, coinciding with a strong thickness gradient of Figure 8a. CAPE is high in the thickness gradient region, but in the state of Rio Grande do Sul it is below $600 \mathrm{~J} / \mathrm{Kg}$ (Figure 8c). The precipitable water shows low values when compared to previous cases, with a maximum of $30 \mathrm{~mm}$ (Figure 8c), probably due to the drier weather in the winter season. Considering the thermodynamic diagram, all thermodynamic indices, Showalter (-3), SWEAT (344), K (40), and Total Totals (52), showed an unstable environment with a high probability for convective storms. As in the other two cases, the height of the freezing level is also low, at $640 \mathrm{hPa}$, which may also contribute to electrification cloud.

Figure 7 - The same as in Figure 3, but July 13, 2015

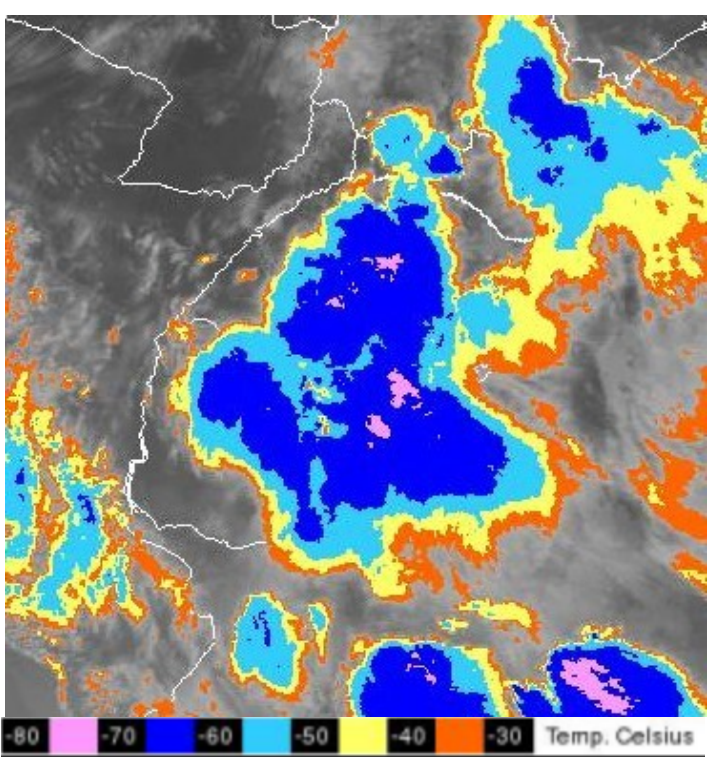

(a)
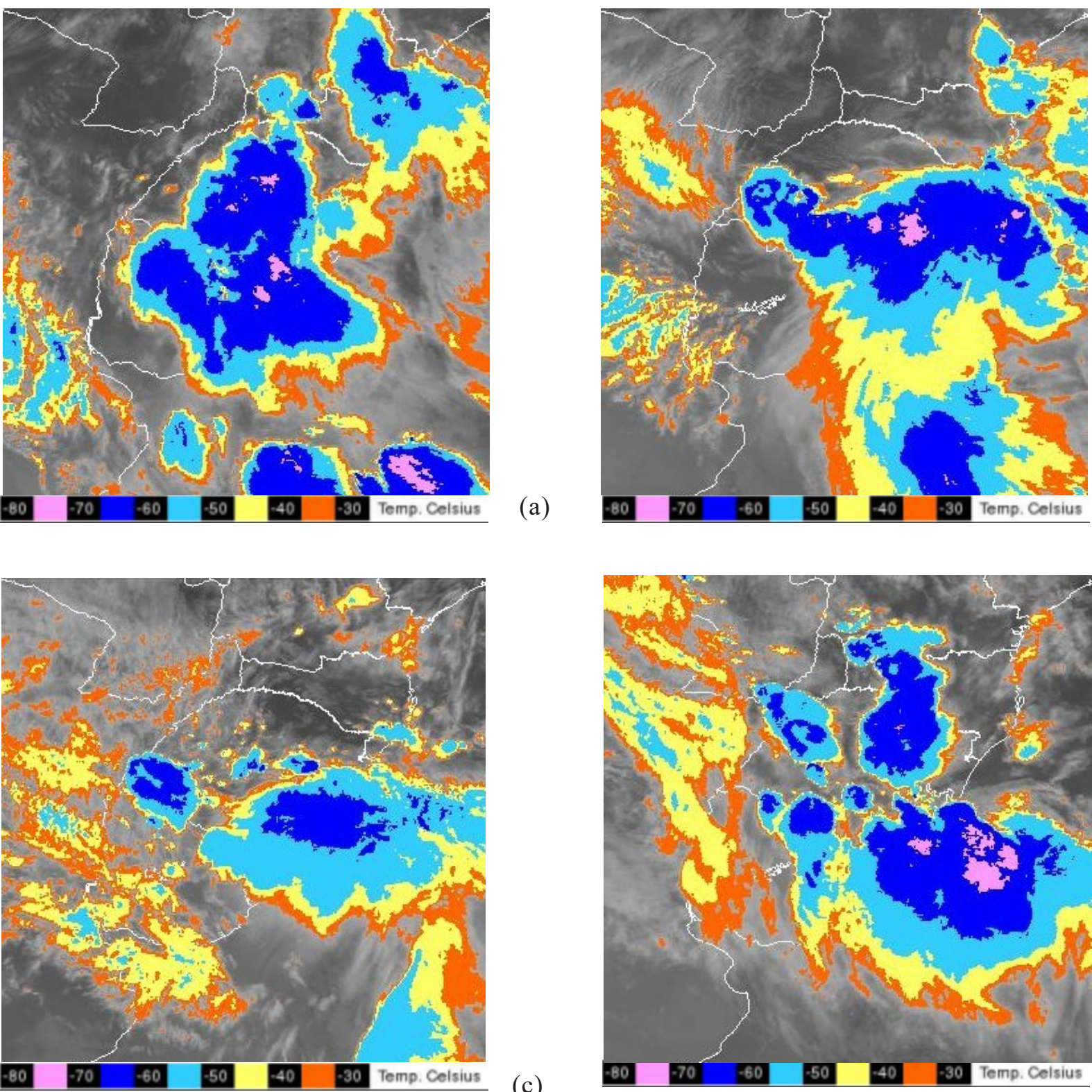

(c)

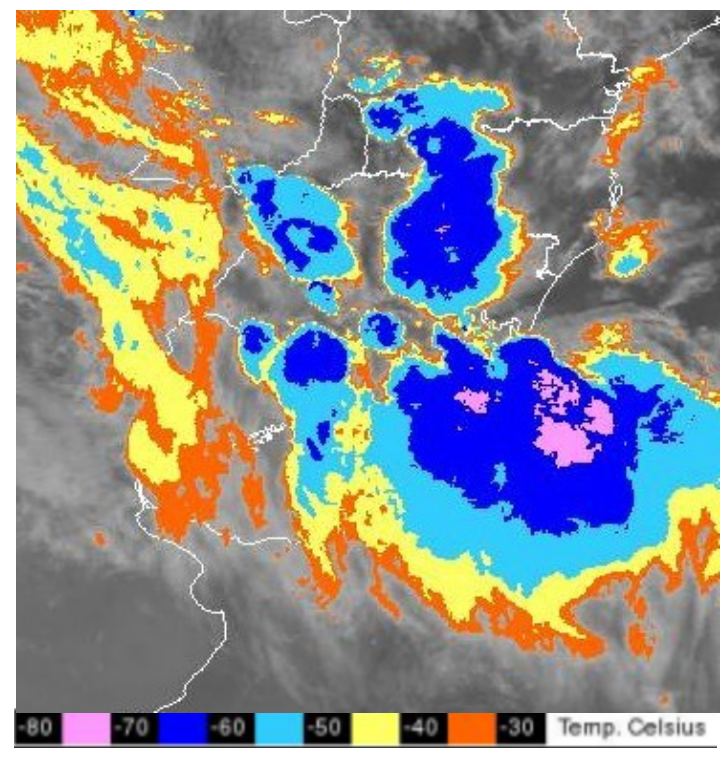




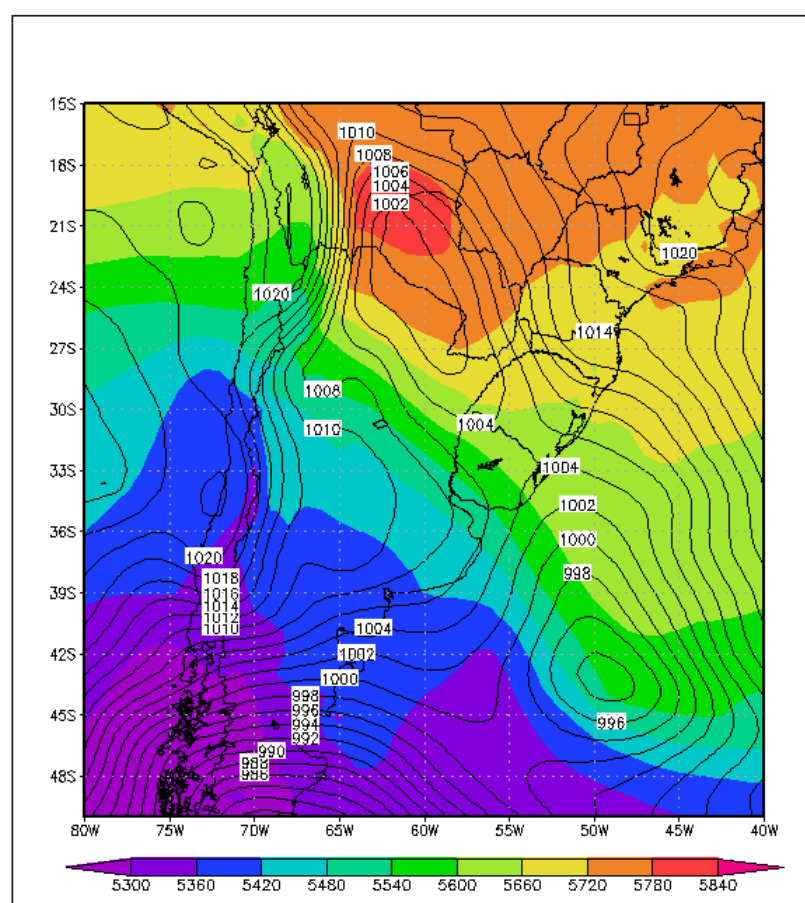

(a)

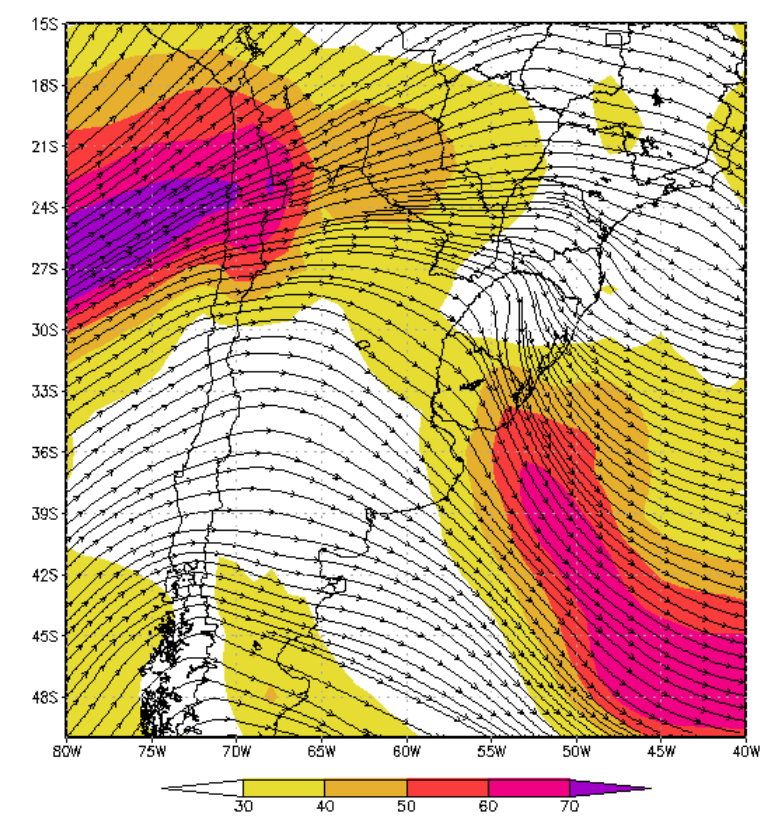

(b)
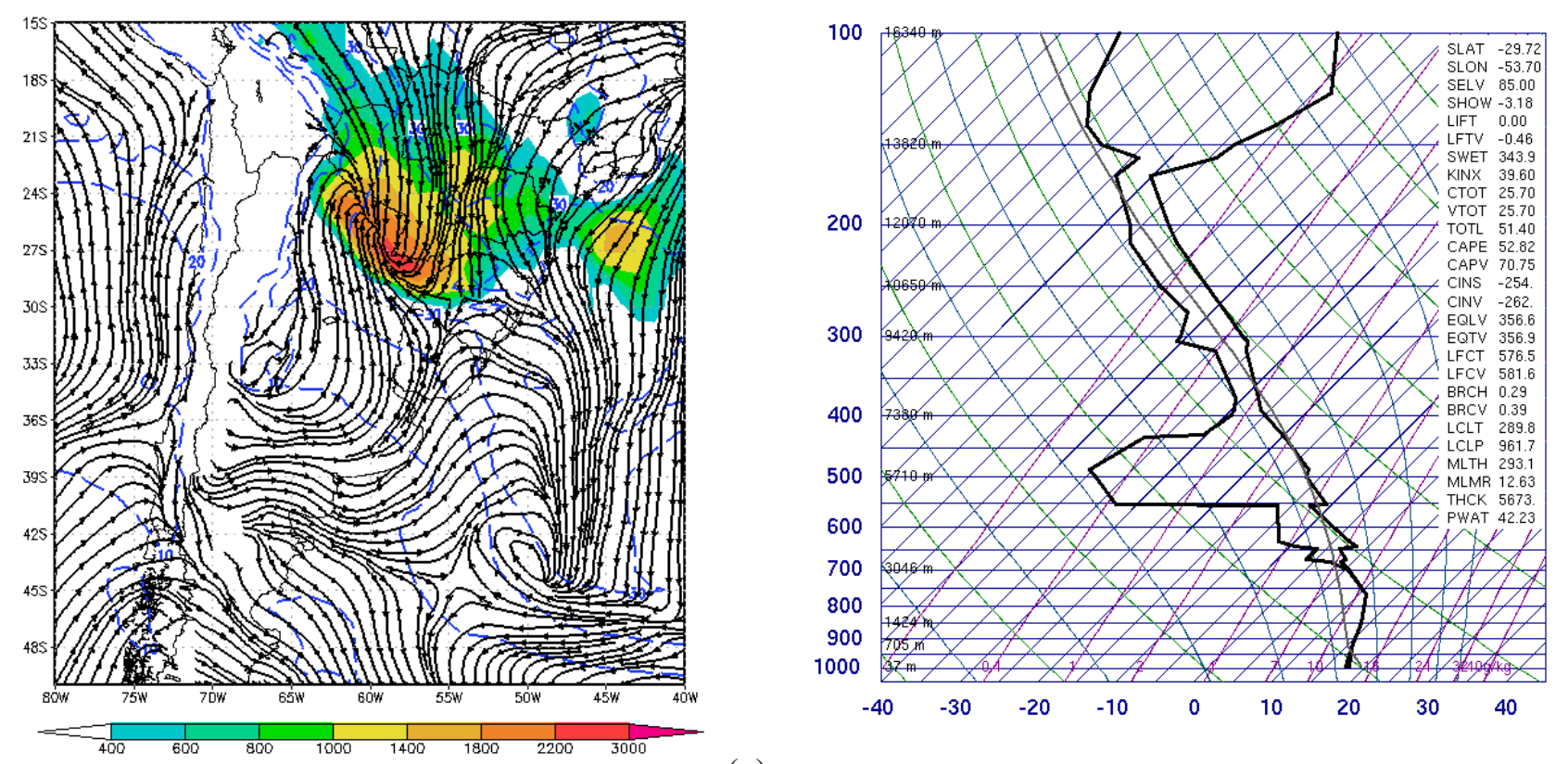

(c)

(d)

The large-scale pattern of meteorological fields associated with days with maximum amount of AED does agree with the patterns found in other studies. Foss (2011) studied the environment associated with severe convective storms in the South American subtropics. The environment favorable to the destabilization of the atmosphere and deep convection was similar to the one found here. According to Santos (2012), the patterns associated with extreme of daily precipitation in the regions bordering Uruguay to the northwest on the state of Rio Grande do Sul were also similar to those of this study. 


\section{Conclusion}

The three cases analyzed allowed to identify some atmospheric characteristics associated with events with large daily amount of AEDs in the vicinity of Santa Maria - in the state of Rio Grande do Sul (Brazil). The characteristics were:

In the SLP field, the first two cases presented a trough in Paraguay and northern Argentina. In the third case, a col configuration over Uruguay and southern on the state of Rio Grande do Sul became evident.

The equatorial entrance of the subtropical jet streak forced the rising motion over the southern Brazil through its transversal circulation. In two of the cases the polar exit of the polar jet streak was also present and fostered upward motion through its transverse circulation.

At high levels there was a shortwave trough over the Argetina in the first case, while in the third case the trough was larger scale. In the second case the high-level flow was zonal.

The low-level flow coming from the Amazon basin advected heat and moisture into the region of study. In the winter case (third event) there is also southern flow, with confluence coinciding with a strong thickness gradient.

The CAPE and precipitable water values were high in the first two cases, while in the third one they were low, since the third one is the only event that occurred in the cold period of the year (July);

The instability indices obtained from thermodynamic profiles indicated moderate-to-high possibility for convective storm occurrence. The third case, in particular, showed indices with greater probability of storms, explaining thus the reason to be the day with a larger number of AED.

In all cases, the height of the freezing level was low, at $600 \mathrm{hPa}$, which contributes to the presence of ice and consequent electrification of the cloud.

The patterns found in this study had no differences with patterns found in other studies, which emphasized severe weather (Foss, 2011) or high precipitation amount (Santos, 2012).

\section{References}

ELAT (2000-2014). Grupo de eletricidade atmosférica. URL http://www.inpe.br/webelat/homepage/menu/ infor/infografico..mortes.por.raios.php.

Foss, M. (2011). Condições atmosféricas conducentes à ocorrência de tempestades convectivas severas na américa do sul. Mestrado em meteorologia, Universidade Federal de Santa Maria, Santa Maria.

Lee, A. C. (1986b). An operational system for the remote location of lightning flashes using a vlf arrival time difference technique. Journal of Atmospheric and Oceanic technology, 3(4), 630-642.

Mattos, E. V. (2009). Relações das propriedades físicas das nuvens convectivas com as descargas elétricas. Mestrado em meteorologia, Instituto Nacional de Pesquisas Espaciais, São José dos Campos.

Mattos, E. V., Machado, L.A. (2011). Cloud-to-ground lightning and mesoscale convective systems. Atmospheric Research, 99(3-4), 377-390.

NCEP (1999). National centers for environmental prediction. URL https://rda.ucar.edu/datasets/ds083.2/.

Pinto Jr, O., de Almeida Pinto, I. R. (2008). Relâmpagos, 2o edn. Brasiliense.

Pinto Jr, P. J., de Almeida Pinto, I. R. C. (2000). Tempestades e relâmpagos no Brasil. Instituto Nacional de Pesquisas Espaciais.

Politi, J., Stephany, S., Domingues, M. O., Junior, O. M. (2006). Mineração de dados meteorológicos associados à atividade convectiva empregando dados de descargas elétricas atmosféricas. Revista Brasileira de Meteorologia, 21(2), $232-244$.

Rasmussen, K., Chaplin, M., Zuluaga, M., Houze Jr, R. (2016). Contribution of extreme convective storms to rainfall in south america. Journal of Hydrometeorology, 17(1), 353-367.

Santos, D. C. (2012). Padrões atmosféricos associados a extremos de precipitação na primavera no estado do rio grande do sul. Mestrado em meteorologia, Universidade Federal de Santa Maria, Santa Maria.

STARNET (2011). Sferics timing and ranging network-starnet-starnet: Evaluation over south america. Em: Proceedings of the 14th International Conference on Atmospheric Electricity-ICAE, Rio de Janeiro, Brazil, URL http://www.zeus.iag. usp. br/contato.php. 
Vanessa Gehm Rodrigues

Universidade Federal de Santa Maria,RS, Brasil

e-mail:vanessagehm@hotmail.com

Participação do autor:

\section{Everson Dal Piva}

Universidade Federal de Santa Maria,RS, Brasil

e-mail: everson.bento@gmail.com

Participação do autor:

\section{Franciano Scremin Puhales}

Universidade Federal de Santa Maria,RS, Brasil

e-mail: franciano.puhales@ufsm.br

Participação do autor:

\section{Vagner Anabor}

Universidade Federal de Santa Maria,RS, Brasil

e-mail: vanabor@gmail.com

Participação do autor: 